рення іiї електронного обліку. Таким чином, лише комплексний підхід до справи може виправити ситуацію і сьогодні українські екологи спираються на контроль сусідніх країн, які входять до ЄC, зокрема V4.

Тому компонентами співпраці України з V4 має бути вирішення питань, пов'язаних із Шацькими озерами та Карпатськими лісами. Ці теми слід включити до списку пріоритетів у плані V4, оскільки саме ця організація виступає за захист безпеки, включаючи екологічну безпеку, в європейському регіоні.

\title{
Література:
}

1. Чекаленко Л. Завданння Вишеграда: угорське головування. Співробітництво з краӥнами Вишеградської четвірки як інструмент європейської інтеграчї та модернізачї Украӥни : матеріали міжнародної конференції (3 жовтня 2013 р., м. Ужгород). К. : НІСД, 2014. C. 89-98.

2. Ukraine floods: Why climate change and logging are blamed. URL: https://www.bbc.com/news/world-europe-53233387.

3. Regulation (EU) No 995/2010 of the European Parliament and of the Council of 20 October 2010 laying down the obligations of operators who place timber and timber products on the market Text with EEA relevance. Official Journal of the European Union. L 295. 2010. P. 23-34.

DOI https://doi.org/10.30525/978-9934-26-040-7-33

\section{ПРАВОВИЙ РЕЖИМ ОХОРОНИ ЗЕМЛІ ЯК ОСНОВНОГО НАЦІОНАЛЬНОГО БАГАТСТВА В УКРАЇНІ}

\author{
Носік В. В. \\ доктор юридичних наук, професор, \\ член-кореспондент Національної академії правових наук України, \\ завідувач кафедри земельного та аграрного права \\ Інституту права \\ Київського національного університету імені Тараса Шевченка \\ м. Київ, Украӥна
}

Відповідно до ст. 14 Конституції України земля є основним національним багатством, що перебуває під особливою охороною держави. При цьому у Конституції Україні не розкривається поняття 
«земля як основне національне багатство». Так само й не визначається, що слід розуміти під особливою охороною землі як основного національного багатства. В українській доктрині земельного права юридична природа цих понять розглядається вченими у різних аспектах: еколого-правовому, соціально-правовому, земельно-правовому. Поки що немає й офіційного тлумачення першого речення частини першої ст. 14 Конституції України від Конституційного Суду України за конституційним поданням народних депутатів України, яке було зроблено у 2019 році. Законодавча і доктринальна невизначеність означених конституційних понять і категорій негативно впливає на практику законотворення та застосування норм земельного та іншого законодавства у правовому забезпеченні охорони землі в Україні.

Науково-теоретичний аналіз змісту норми першого речення частини першої Конституції України дозволяє стверджувати, що у цій нормі Основного закону держави встановлюється особливий режим правової охорони землі державно-правовими засобами на національному рівні, а також у відносинах з іншими суб'єктами міжнародного права.

Об'єктом особливої охорони виступає земля, яка за ст. 13 Конституції України, належить Українському народу на праві власності. Від імені держави суб'єктами особливої охорони землі виступають органи державної влади і місцевого самоврядування, які реалізують свої функції i повноваження щодо охорони землі як основного національного багатства у межах, визначених Конституцією України на міждержавному, національному, регіональному та місцевому рівнях.

Особливий режим правової охорони землі зобов'язує органи державної влади забезпечити реалізацію конституційних гарантій здійснення права власності Українського народу на землю та визначати правовий режим землі як основи національного суверенітету України та використання природних властивостей поверхні суші землі, іiі надр, атмосферного повітря, водних та інших природних ресурсів у межах території України, а також природних ресурсів іiі континентального шельфу, виключної (морської) економічної зони. Держава також зобов'язана встановлювати юридичну відповідальність за порушення Конституції України та чинного законодавства 3 питань здійснення права власності на землю, використання та охорони землі у межах території України.

За змістом норми статті 14 Конституції України поняття «земля» тотожним терміну «земля» у контексті норми ст. 13 Конституції України. Відтак, закріплені у нормі ст.14 Конституції України ознаки землі як «основне», «національне», «багатство» визначають правові межі діяльності органів державної влади і місцевого самоврядування 
щодо забезпечення в інтересах всього Українського народу правового режиму особливої охорони землі за ії функціональним призначенням як головного засобу виробництва у сільському і лісовому господарстві, територіальної основи національного суверенітету, адміністративнотериторіального устрою, просторового операційного базису, підвищення родючості грунтів на землях сільськогосподарського і лісогосподарського призначення, використання, збереження і відтворення надр, атмосферного повітря, природних ресурсів екологічних систем суші і моря, забезпечення соціального розвитку економіки і захист права власності Українського народу на землю.

Оскільки земля, як основне національне багатство, є об' єктом права власності Українського народу, то правовий режим особливої охорони передбачає, що органи державної влади і місцевого самоврядування згідно ст. 13 Конституції України, зобов'язані забезпечити виключно громадянам України право доступу до використання земельних ділянок за їх функціональним призначенням на праві власності чи інших правових титулах, передбачених законом. Водночас юридичні особи України можуть використовувати земельні ділянки на праві власності, яке у встановленому законом порядку набули громадяни України для здійснення статутної діяльності у обраній ними організаційно-правовій формі. При цьому правовий режим особливої охорони землі як основного національного багатства виключає можливості перетворення землі у цінні папери акціонерних товариств та обіг таких цінних паперів на фондових ринках. Правовий режим особливої охорони землі як основного національного багатства зобов'язує органи законодавчої влади забезпечити реалізацію норм ст. 13 Конституції України, за якою іноземні громадяни, особи без громадянства, іноземні держави i міжнародні організації, іноземні юридичні особи не можуть бути власниками земельних ділянок, а також використовувати надра та інші природні ресурси на праві власності у межах території України, континентального шельфу, виключної (морської) економічної зони.

Особливий режим охорони землі як основного національного багатства зобов'язує державу в особі органів державної влади та місцевого самоврядування забезпечити за допомогою норм внутрішнього і міжнародного права реалізацію закріпленого у Конституції України принципу територіального верховенства, недоторканості землі як територіальної основи національного суверенітету і об'єкта права власності Українського народу. Конституційні імперативи щодо територіальної цілісності і недоторканності кордонів держави забезпечують непорушність і стабільність права власності Українського народу на землю в межах існуючих кордонів і не дозволяють будь яких посягань на землю з боку інших суб'єктів міжнародного права, а 136 
також забороняють сепаратистські дії, спрямовані на внутрішній розподіл території держави чи відокремлення частини території або іiі адміністративно-територіальних одиниць всупереч національним інтересам Українського народу як власника землі. Крім того, конституційна сутність цілісності території означає, що земля як об'єкт права власності Українського народу не може відчужуватись іншим державам.

За Конституцією України правовий режим особливої охорони землі як основного національного багатства забороняє органам державної влади чи місцевого самоврядування самостійно розпоряджатись державною територією та відчужувати землю як об'єкт права власності Українського народу іншим суб'єктам міжнародного права. Згідно ст. 73 Основного закону держави, виключно Всеукраїнським референдумом вирішуються питання про зміну території України. Виходячи 3 цього, ніхто в Україні не може прийняти рішення про відчуження державної території та землі як об'єкта права власності Українського народу без проведення референдуму і волевиявлення народу України щодо зміни території держави, що є однією з важливих інституційноправових гарантій забезпечення стабільності і непорушності права власності Українського народу на землю, а також запобігання можливим зловживанням з боку органів державної влади щодо розпорядження територією на міжнародній арені.

Відповідно до Конституції України правовий режим особливої охорони державою землі як основного національного багатства, що належить Українському народові на праві власності, передбачає реалізацію норм-принципів Основного закону держави, у яких закріплюються форми і способи захисту недоторканності та цілісності державної території i водночас непорушності права власності Українського народу на землю. Тому порушення державного кордону іноземними державами і особами є не лише посяганням на територіальну цілісність і недоторканність, а й порушенням у будь якій формі (окупація, анексія, насильнице захоплення території, незаконний проїзд чи прохід по території, самовільне захоплення земельних ділянок, порушення права загального землекористування, незаконне використання природних ресурсів, інші порушення прикордонного режиму, тощо) правомочностей Українського народу на володіння, користування і розпорядження землею як об'єктом права власності.

Закріплений у Конституції України особливий режим правової охорони землі як основного національного багатства передбачає, що Україна, як суб'єкт міжнародного права, в особі органів державної влади, керуючись міжнародно-правовими принципами поваги державного суверенітету, територіальної цілісності і недоторканності території, договірного режиму державного кордону, має право вирішу- 
вати всі питання щодо територіального верховенства і здійснення прав власника на землю Українського народу шляхом проведення переговорів та укладення міждержавних угод 3 питань врегулювання територіальних претензій з боку інших держав, встановлення лінії державного кордону, повернення тих чи інших земель до власності Українського народу тощо.

3 метою захисту суверенітету і цілісності державної території та непорушності права власності Українського народу на землю, Україна через свої центральні ограни державної влади може вирішувати територіальні спори шляхом звернення у встановленому порядку до міжнародних інституцій ООН та $\mathrm{CC}$, або ж відстоювати у цих організаціях свої права від претензій інших суб'єктів міжнародного права щодо незалежності, недоторканності, цілісності території, непорушності державного кордону i водночас забезпечувати право власності Українського народу на землю.

DOI https://doi.org/10.30525/978-9934-26-040-7-34

\title{
ДО ПИТАННЯ ПРО ПРАВОВІ ПРОБЛЕМИ МОНІТОРИНГУ ЯКОСТІ АТМОСФЕРНОГО ПОВІТРЯ В УКРАЇНI
}

\author{
Чурилова Т. М. \\ кандидат юридичних наук, дочент, \\ доиент кафедри міжнародного, європейського права \\ та ичивільно-правових дисциилін \\ Сумського державного університету \\ м. Суми, Украӥна \\ Стрельник В. В. \\ кандидат юридичних наук, доцент, \\ дочент кафедри приватного та сочуіального права \\ Сумського національного аграрного університету \\ м. Суми, Украӥна
}

Належна якість атмосферного повітря $\epsilon$ запорукою загального процвітання і благополуччя. Забруднене повітря негативно позначається не тільки на здоров’ї людей, а й впливає на екосистеми, клімат, 